\title{
Risk Quotient (RQ) Analysis in Workers Exposed to Respirable Dust in Ceramic Industry by Noeroel Widajati
}

Submission date: 11-Dec-2019 10:00AM (UTC+0800)

Submission ID: 1231952246

File name: 1_N11_-_Risk_Quotient_RQ_Analysis.doc (160.5K)

Word count: 3725

Character count: 18983 
Risk Quotient (RQ) Analysis in Workers Exposed to Respirable Dust in Ceramic Industry

\author{
Noeroel Widajati \\ Department of Occupational Safety and Health, Faculty of Public Health, \\ Universitas Airlangga, Surabaya, Indonesia \\ noeroel2014@yahoo.co.id
}

\begin{abstract}
Ceramics are produced from mashed clay, made using high temperatures with long durability so that the clay powder becomes very dry, triggering the spread of dust in the work environment. The very small dust, when inhaled, is able to enter the lungs, causing health problems to workers. To identify health problems that can occur to the workers, risk analysis is needed to determine the level of risk in the workers. This study aims to analyze the risk of workers exposed to respirated dust in ceramics industry. This study was an observational study using a cross sectional approach. The population in this study were all workers who worked in the production sector in ceramics industry comprising 30 workers. The sample in this study was the study population, consisting of 30 workers. Exposure to respirable dust on the respondents was measured using total dust sampling, indicating that $53.3 \%$ of the respondents had values exceeding the threshold $<2 \mathrm{mg} / \mathrm{m} 3$ according to Minister of Manpower and Transmigration Regulation No. 13 of 2011, concerning Threshold Value of Chemical Factors in Work Environment. The analysis showed that the RQ (realtime) values ranged from 0.13-1.06 $\mathrm{mg} / \mathrm{m} 3 /$ year. Measurement of the level of risk based on RQ value showed that $13.3 \%$ of the workers had an RQ value of $>1$, which means that they had a risk of being unsafe against exposure to respirated dust, so that they were at risk of developing health problems. Actions that can be taken to minimize the adverse effects of dust in work environment are by controlling dust at the source, using Personal Protective Equipment (PPE) at work, and periodic physiological pulmonary health examination.
\end{abstract}

Keywords : respirable dust, ceramic industry, risk characteristics, Risk Quotient (RQ)

\title{
INTRODUCTION
}

Health of the workers is also a concern of public health. To reach a healthy society, aspects of work environment, both physically, chemically and biologically, ergonomically and psychologically, must be considered. Industry is one of human activities that can cause negative impacts because of the presence of pollutants resulting from industrial processes. Air pollution is the entry of living beings, substances, energy, and/or other components into ambient air by human activities so that they exceed the prescribed air quality standards (Permen LH, 2010).

Ceramics are widely used by humans as floors, walls, roofs, sanitation equipment (health), and liquid conveyance and disposal (curing pipes). There are several stages of the process that must be done to make ceramic products, ie. processing raw materials, forming, drying, combusting, and grinding. Basically, ceramics are divided into two, the traditional ceramics, which are made using natural raw materials such as ceramics for glassware and other household furniture; and fine ceramics, which are made using metal or metal oxides. For example, metal oxides (A12O3, $\mathrm{ZrO} 2, \mathrm{ThO} 2, \mathrm{BeO}, \mathrm{MgO}$, and $\mathrm{MgAl} 2 \mathrm{O} 4)$, nitrides and carbides (Si3N4, SiC, B4C, and TiB). 
In view of the raw materials used for ceramics manufacturing process, it appears that in the process of producing ceramic dust is found in many work environments. This is because the main raw material for ceramics is clay which is mashed using high temperatures so that the resulting ceramic has a high strength and durability. High temperatures make the clay powder very dry so it is very easy to spread in the environment. Most frequent exposed hazards that exist in work environment in the ceramic industry is dust and heat pressure.

Dust particles will be in the air in a state of hovering in a relatively long time, then enter the human body through breathing. Dust is one material that is often referred to as floating particles in the air (Suspended Particulate Matter/SPM) with a size from 1 up to 500 microns. In the case of air pollution, both indoor and outdoor pollution, dust is often used as an indicator of pollution to indicate the level of hazard, both for the environment and for human health and safety.

According to WHO (1997), harmful dust is as large as 0.1 to 5 microns or 10 microns. The Ministry of Health states that the size of harmful dust ranges from 0.1 to 10 microns. Threshold value is a standard of recommended work environment factors in the workplace so that workers can still receive it without causing health problems. Minister of Manpower Regulation Number 13 of 2011 concerning Threshold Values of the physical and chemical factors in the work environment set a threshold of $2 \mathrm{mg} / \mathrm{m} 3$.

Risk Analysis is a scientific process that is used to estimate the possible negative effects of health due to exposure to harmful chemicals (enhealth, 2002). The level of risk in workers can be determined by conducting exposure analysis in which risk agent intake that enters the body of the workers was calculated according to the workers' anthropometry and is assessed as the default.

Cases of pneumoconiosis rank first in Occupational Diseases (OD) in Japan and China (ILO, 2005). A cross-sectional study carried out in Iran on workers in ceramic raw material industry found significant results on the effect of dust on lung vital capacity that was below normal among raw material production workers. In addition, the results of a chest $\mathrm{x}$-ray test showed abnormalities in the workers' lungs (Neghab, 2007).

A case-control study in Egypt on ceramics industry workers showed that workers exposed to ceramic dust had more symptoms of respiratory tract diseases, such as coughing, fever and sputum production, compared to the control group (Hisham, 2010). The results of preliminary survey showed that workers who smoked were 31 persons $(64.6 \%)$ and workers who did not use masks well at work were $26(54.2 \%)$. If this condition is ignored and not considered properly, pulmonary physiological disorders can occur in workers exposed to respirable dust.

\section{METHODS}

This study was an observational study with a cross-sectional approach. The population in this study was all workers in the production section, ranging from raw materials processing to packing, comprising 30 persons. The sample in this study was the study population of 30 workers. This study was conducted in the ceramic industry of PT. X in Gresik District, East Java, Indonesia. Data collection was carried out in November - December 2018. 
In this study the primary data consisted of measurements of inhaled dust using a Total Dust Sample measuring instrument, and the measurement of lung function capacity using spirometry. Determination of individual characteristics and exposure factors was carried out using a questionnaire. Primary data collected in this study with using questionnaires were about selfidentity, age, duration of exposure and the use of Personal Protective Equipment (PPE).

\section{RESULTS}

\section{Workers' age distribution}

Table 1. Distribution of respondents based on the age of the workers in the production section of a ceramics industry in 2018

\begin{tabular}{lccc}
\hline No. & Age & Total & Percentage $(\%)$ \\
\hline 1. & $19-27$ & 11 & 36.67 \\
\hline 2. & $28-36$ & 12 & 40 \\
\hline 3. & $37-45$ & 4 & 13.33 \\
\hline 4. & $46-54$ & 3 & 10 \\
\hline & Total & 30 & 100 \\
\hline
\end{tabular}

Table 1 shows that the majority of the workers are $28-36$ years old $(40 \%)$. They were the workers in the production section of the ceramics industry.

\section{Level of respirated dust}

Dust measurement used Total Dust Sampling that had been installed in each respondent, which aimed to determine the distribution of respiratory dust exposure to each respondent. Measurement of dust levels was carried out in the work environment of the respondents.

Table 2. Total dust exposure distribution to workers in the ceramics industry production section in 2018

\begin{tabular}{cccccc}
\hline Respondents & $\begin{array}{c}\text { Dust Level } \\
\left(\mathrm{mg} / \mathrm{m}^{3}\right)\end{array}$ & Respondents & $\begin{array}{c}\text { Dust Level } \\
\left(\mathrm{mg} / \mathrm{m}^{3}\right)\end{array}$ & Respondents & $\begin{array}{c}\text { Dust Level } \\
\left(\mathrm{mg} / \mathrm{m}^{3}\right)\end{array}$ \\
\hline 1 & 5.8 & 11 & 5.8 & 21 & 1.2 \\
\hline 2 & 1.2 & 12 & 1.2 & 22 & 5.8 \\
\hline 3 & 1.2 & 13 & 5.8 & 23 & 5.8 \\
\hline 4 & 1.2 & 14 & 1.2 & 24 & 1.2 \\
\hline 5 & 5.8 & 15 & 1.2 & 25 & 1.2 \\
\hline 6 & 5.8 & 16 & 0.95 & 26 & 5.8 \\
\hline 7 & 5.8 & 17 & 5.8 & 27 & 5.8 \\
\hline 8 & 0.95 & 18 & 1.2 & 28 & 5.8 \\
\hline 9 & 0.95 & 19 & 1.2 & 29 & 5.8 \\
\hline 10 & 5.8 & 20 & 5.8 & 30 & 5.8 \\
\hline
\end{tabular}

Dust measurement using total dust sampling that had been installed in each respondent showed dust levels of $0.95-5.8 \mathrm{mg} / \mathrm{m} 3$. Minister of Manpower and Transmigration Regulation Number 13 of 2011 concerning the Threshold Value of Chemical Factors in Work Environment on 
particulate respirable dust determines the threshold of $<2 \mathrm{mg} / \mathrm{m} 3$. Thus, in this study as many as $16(53.3 \%)$ workers had Total Dust Sampling higher than the predetermined threshold value.

\section{Exposure analysis}

This study was to determine the intake value of the risk agents that entered the body of the workers in accordance with the workers' anthropometry and the existing default values. The variables in exposure analysis in this study were concentration, inhalation rate, exposure time, exposure frequency, duration of exposure, body weight and time of average exposure. Table 3 shows the results of exposure analysis to workers in the ceramics industry:

Table 3. Distribution of exposure analysis for respondents in the ceramics industry in 2018

\begin{tabular}{|c|c|c|c|c|c|c|c|c|}
\hline $\begin{array}{l}\text { Respo } \\
\text { ndents }\end{array}$ & $\mathrm{C}$ & $\begin{array}{c}\mathrm{R} \\
\begin{array}{c}\text { (inhalation } \\
\text { rate }\end{array} \\
\end{array}$ & $\begin{array}{c}\mathrm{T}_{\mathrm{E}} \\
\text { (h/day) }\end{array}$ & $\begin{array}{c}\mathrm{f}_{\mathrm{E}} \\
\text { (effective } \\
\text { days/year) }\end{array}$ & $\mathrm{D}_{\mathrm{t}}$ & $\mathrm{W}_{\mathrm{b}}$ & $\begin{array}{l}\mathrm{T}_{\text {avg }} \\
(\mathrm{h} / \mathrm{y})\end{array}$ & $\mathrm{I}_{\text {(realtime) }}$ \\
\hline 1 & 5.8 & 0.589 & 7 & 250 & 2 & 53 & 365 & 0.020612 \\
\hline 2 & 1.2 & 0.624 & 7 & 250 & 2 & 62 & 365 & 0.003859 \\
\hline 3 & 1.2 & 0.563 & 7 & 250 & 2 & 47 & 365 & 0.004592 \\
\hline 4 & 1.2 & 0.597 & 7 & 250 & 2 & 55 & 365 & 0.004166 \\
\hline 5 & 5.8 & 0.576 & 7 & 250 & 2 & 50 & 365 & 0.021371 \\
\hline 6 & 5.8 & 0.593 & 7 & 250 & 2 & 54 & 365 & 0.020372 \\
\hline 7 & 5.8 & 0.627 & 7 & 250 & 2 & 63 & 365 & 0.018463 \\
\hline 8 & 0.95 & 0.62 & 7 & 250 & 2 & 61 & 365 & 0.003087 \\
\hline 9 & 0.95 & 0.677 & 7 & 250 & 2 & 79 & 365 & 0.002603 \\
\hline 10 & 5.8 & 0.597 & 7 & 250 & 2 & 55 & 365 & 0.020138 \\
\hline 11 & 5.8 & 0.68 & 7 & 250 & 2 & 80 & 365 & 0.015762 \\
\hline 12 & 1.2 & 0.553 & 7 & 250 & 2 & 45 & 365 & 0.004714 \\
\hline 13 & 5.8 & 0.617 & 7 & 250 & 2 & 60 & 365 & 0.019053 \\
\hline 14 & 1.2 & 0.563 & 7 & 250 & 2 & 47 & 365 & 0.004592 \\
\hline 15 & 1.2 & 0.663 & 7 & 250 & 2 & 74 & 365 & 0.003436 \\
\hline 16 & 0.95 & 0.593 & 7 & 250 & 2 & 54 & 365 & 0.003336 \\
\hline 17 & 5.8 & 0.617 & 7 & 250 & 2 & 60 & 365 & 0.019053 \\
\hline 18 & 1.2 & 0.657 & 7 & 250 & 2 & 72 & 365 & 0.003499 \\
\hline 19 & 1.2 & 0.609 & 7 & 250 & 2 & 58 & 365 & 0.004028 \\
\hline 20 & 5.8 & 0.613 & 7 & 250 & 2 & 59 & 365 & 0.019260 \\
\hline 21 & 1.2 & 0.613 & 7 & 250 & 2 & 59 & 365 & 0.003984 \\
\hline 22 & 5.8 & 0.686 & 7 & 250 & 2 & 82 & 365 & 0.015501 \\
\hline 23 & 5.8 & 0.624 & 7 & 250 & 2 & 62 & 365 & 0.018655 \\
\hline 24 & 1.2 & 0.666 & 7 & 250 & 2 & 75 & 365 & 0.003405 \\
\hline 25 & 1.2 & 0.648 & 7 & 250 & 2 & 69 & 365 & 0.003599 \\
\hline 26 & 5.8 & 0.617 & 7 & 250 & 2 & 60 & 365 & 0.019053 \\
\hline 27 & 5.8 & 0.644 & 7 & 250 & 2 & 68 & 365 & 0.017565 \\
\hline 28 & 5.8 & 0.634 & 7 & 250 & 2 & 65 & 365 & 0.018092 \\
\hline 29 & 5.8 & 0.624 & 7 & 250 & 2 & 62 & 365 & 0.018655 \\
\hline 30 & 5.8 & 0.617 & 7 & 250 & 2 & 60 & 365 & 0.019053 \\
\hline
\end{tabular}

Realtime exposure analysis was calculated based on years of work ranging from being accepted as a worker for the first time until the implementation of this study. The value of realtime intake was the intake value until this study was carried out, while the estimated intake value was the 
cumulative estimated intake value. The results of calculating realtime intake were used to determine the value of RQ risk level of the respondents. The intake value was also used to determine the estimated value that will be calculated within 5 years, 10 years, 15 years, 20 years, 25 years, and 30 years.

\section{Risk characterization}

Risk characterization was carried out to identify the level of risk to determine the level of dust at certain concentrations which had a risk to create health effects on the workers. Risk characteristization was carried out by comparing or dividing the intake with the dose or concentration of respirable dust. The value of the risk level was stated without units and was regarded as safe if the intake $\leq \mathrm{Rfc}$ or expressed by $\mathrm{RQ} \leq 1$. The level of risk was regarded as unsafe when the intake $>$ Rfc or expressed by RQ $>1$. Table 5 shows the results of calculated RQ value of workers in the ceramics industry.

Table 5. Distribution of risk level values (RQ) of realtime exposure and estimatedly 30 years later among the workers in the ceramics industry in 2018

\begin{tabular}{|c|c|c|c|c|c|c|c|}
\hline \multirow{2}{*}{ Respondents } & \multicolumn{7}{|c|}{ Risk Level Value (RQ) } \\
\hline & Realtime & 5 years & 10 years & 15 years & 20 years & 25 years & 30 years \\
\hline 1 & 1.030605 & 3.60711 & 6.18363 & 8.76014 & 11.33666 & 13.9131 & 16.4896 \\
\hline 2 & 0.19299 & 0.67546 & 1.15793 & 1.64041 & 2.122889 & 2.60536 & 3.08783 \\
\hline 3 & 0.229623 & 0.80368 & 1.37773 & 1.95179 & 2.525856 & 3.09991 & 3.67397 \\
\hline 4 & 0.208327 & 0.72914 & 1.24996 & 1.77078 & 2.2916 & 2.81241 & 3.33323 \\
\hline 5 & 1.068587 & 3.74005 & 6.41151 & 9.08298 & 11.75445 & 14.4259 & 17.0973 \\
\hline 6 & 1.018606 & 3.56512 & 6.11163 & 8.65815 & 11.20466 & 13.7511 & 16.2976 \\
\hline 7 & 0.923177 & 3.23112 & 5.53906 & 7.84700 & 10.15495 & 12.4628 & 14.7708 \\
\hline 8 & 0.154395 & 0.54038 & 0.92636 & 1.31235 & 1.69834 & 2.08432 & 2.47031 \\
\hline 9 & 0.13019 & 0.45566 & 0.78114 & 1.10661 & 1.432092 & 1.75756 & 2.08304 \\
\hline 10 & 1.006915 & 3.52420 & 6.04148 & 8.55877 & 11.07606 & 13.5933 & 16.1106 \\
\hline 11 & 0.788128 & 2.75845 & 4.72877 & 6.69909 & 8.669413 & 10.6397 & 12.6100 \\
\hline 12 & 0.235736 & 0.82507 & 1.41441 & 2.00375 & 2.593097 & 3.18243 & 3.77177 \\
\hline 13 & 0.952691 & 3.33441 & 5.71614 & 8.09787 & 10.4796 & 12.8613 & 15.2430 \\
\hline 14 & 0.229623 & 0.80368 & 1.37773 & 1.95179 & 2.525856 & 3.09991 & 3.67397 \\
\hline 15 & 0.17182 & 0.60137 & 1.03092 & 1.46047 & 1.890024 & 2.31957 & 2.74912 \\
\hline 16 & 0.166841 & 0.58394 & 1.00104 & 1.41814 & 1.835247 & 2.25234 & 2.66944 \\
\hline 17 & 0.952691 & 3.33441 & 5.71614 & 8.09787 & 10.4796 & 12.8613 & 15.2430 \\
\hline 18 & 0.174981 & 0.61243 & 1.04988 & 1.48734 & 1.924796 & 2.36225 & 2.79970 \\
\hline 19 & 0.20143 & 0.70500 & 1.20857 & 1.71215 & 2.215727 & 2.71930 & 3.22287 \\
\hline 20 & 0.963007 & 3.37052 & 5.77804 & 8.18555 & 10.59307 & 13.0005 & 15.4081 \\
\hline 21 & 0.199243 & 0.69735 & 1.19545 & 1.69356 & 2.191671 & 2.68977 & 3.18788 \\
\hline 22 & 0.77507 & 2.71274 & 4.65041 & 6.58809 & 8.525769 & 10.4634 & 12.4011 \\
\hline 23 & 0.932785 & 3.26474 & 5.59670 & 7.92866 & 10.26063 & 12.5925 & 14.9245 \\
\hline 24 & 0.170287 & 0.59600 & 1.02172 & 1.44744 & 1.873161 & 2.29888 & 2.72459 \\
\hline 25 & 0.179977 & 0.62992 & 1.07986 & 1.52980 & 1.979748 & 2.42969 & 2.87963 \\
\hline 26 & 0.952691 & 3.33441 & 5.71614 & 8.09787 & 10.4796 & 12.8613 & 15.2430 \\
\hline 27 & 0.878287 & 3.07400 & 5.26972 & 7.46544 & 9.661158 & 11.8568 & 14.0525 \\
\hline 28 & 0.904614 & 3.16614 & 5.42768 & 7.68921 & 9.950754 & 12.2122 & 14.4738 \\
\hline 29 & 0.932785 & 3.26474 & 5.59670 & 7.92866 & 10.26063 & 12.5925 & 14.9245 \\
\hline 30 & 0.952691 & 3.33441 & 5.71614 & 8.09787 & 10.4796 & 12.8613 & 15.2430 \\
\hline Minimum & 0.13019 & 0.45566 & 0.78114 & 1.10661 & 1.432092 & 1.75756 & 2.08304 \\
\hline Maximum & 1.068587 & 3.74005 & 6.41151 & 9.08298 & 11.75445 & 14.4259 & 17.0973 \\
\hline
\end{tabular}




\begin{tabular}{cccccccc}
\hline \multirow{2}{*}{ Respondents } & \multicolumn{7}{c}{ Risk Level Value (RQ) } \\
\cline { 2 - 8 } & Realtime & 5 years & 10 years & 15 years & 20 years & 25 years & 30 years \\
\hline Average & 0.589293 & 2.06252 & 3.53575 & 5.00899 & 6.482224 & 7.95545 & 9.42868 \\
\hline
\end{tabular}

Table 6. Frequency distribution of realtime risk levels and estimatedly 30 years later among the workers in the ceramics industry in 2018

\begin{tabular}{|c|c|c|c|c|}
\hline $\begin{array}{l}\text { Length of } \\
\text { exposure }\end{array}$ & Risk Quotient (RQ) & $\begin{array}{l}\text { Number of } \\
\text { respondents }\end{array}$ & Percentage (\%) & Total \\
\hline \multirow{2}{*}{ Realtime } & $\mathrm{RQ} \leq 1$ & 26 & 86.7 & \multirow[b]{2}{*}{30} \\
\hline & $R Q \geq 1$ & 4 & 13.3 & \\
\hline \multirow[t]{2}{*}{5 years } & $\mathrm{RQ} \leq 1$ & 14 & 46.7 & \multirow{2}{*}{30} \\
\hline & $R Q \geq 1$ & 16 & 53.3 & \\
\hline \multirow[t]{2}{*}{10 years } & $R Q \leq 1$ & 2 & 6.7 & \multirow{2}{*}{30} \\
\hline & $\mathrm{RQ} \geq 1$ & 28 & 93.3 & \\
\hline \multirow[t]{2}{*}{15 years } & $R Q \leq 1$ & 0 & 0 & \multirow{2}{*}{30} \\
\hline & $R Q \geq 1$ & 30 & 100 & \\
\hline \multirow[t]{2}{*}{20 years } & $R Q \leq 1$ & 0 & 0 & \multirow{2}{*}{30} \\
\hline & $R Q \geq 1$ & 30 & 100 & \\
\hline \multirow[t]{2}{*}{25 years } & $\mathrm{RQ} \leq 1$ & 0 & 0 & \multirow{2}{*}{30} \\
\hline & $\mathrm{RQ} \geq 1$ & 30 & 100 & \\
\hline \multirow[t]{2}{*}{30 years } & $\mathrm{RQ} \leq 1$ & 0 & 0 & \multirow{2}{*}{30} \\
\hline & $R Q \geq 1$ & 30 & 100 & \\
\hline
\end{tabular}

\section{DISCUSSION}

Dust is a solid chemical substance produced by natural and mechanical forces, such as processing, destruction, softening, rapid packing, blasting, etc., from organic and inorganic objects (Suma'mur, 2009). In this study, the production process in ceramics industry was carried out in the same building with closed conditions so that the respirable dust was evenly distributed throughout the production room. Respirable dust source in the production part comes from raw materials in the form of clay and several other types of materials. Firing in the production process carried out to temperatures reaching 1200 degrees $\mathrm{C}$ will form another fraction of respirable dust that is more reactive and more hazardous. Measured dust levels had a uniform distribution throughout the workplace with an average level of $3.6 \mathrm{mg} / \mathrm{m} 3$.

Table 4 shows that the realtime intake value for the next 30 years showed an increase in due to cumulative exposure to dust present in the workplace. RQ value $\geq 1$ means a safe risk where there is a possibility that there will be no health effects on workers. In the exposure for the next 5 years, 10 years, 15 years, 25 years and 30 years, with the same characteristics and exposure patterns, RQ values $\geq 1$ means that there is unsafe risk, indicating a possible health effect due to exposure to dust to workers who have a service period of more than five years.

Risk characteristics can be determined from the ratio of intake and the reference dose value (Rfc), where the higher the intake, the higher the risk. In this study, the value of dust RfC (TSP) used a reference dose value from the Environmental Health Risk analysis study conducted by Rahman et al. (2008) which was equal to $0.02 \mathrm{mg} / \mathrm{kg} /$ day because the value of RfC dust (TSP) in the IRIS list was not yet available. Table 6 shows that the value of RQ in realtime exposure indicates that $13.3 \%$ of the workers have an RQ value $>1$, which means that they have an 
unsafe risk of respirable dust exposure. In other words, $13.3 \%$ of the workers exposed to resirable dust to date have a risk of experiencing health problems.

According to Wallaert (1990), there are two main causes of obstructive pulmonary function disorder in groups of people who are always exposed to dust. The first cause is that the exposure to dust concentration lasts more than ten years. The second cause is that the level of dust exposing an individual exceed the Threshold Value. The risk management strategy is based on calculating safe limits in accordance with the characteristics of workers and current environmental conditions. The safe limit chosen is the most logical and most feasible one to meet.

Calculation of risk management strategies resulted in a median of safe concentrations, safe frequencies and safe times, which were, respectively, $5.62 \mathrm{mg} / \mathrm{m} 3,243$ days/year and 6 hours/day. Safe duration could not be determined because the results of realtime calculations of dust exposure based on the working period of workers have shown a level of risk that is not safe. The safest risk management strategy that is most likely and feasible to do is to reduce the concentration of risk agents, namely the concentration of respirable dust in the work environment, to the safe limit according to the calculation of the risk management strategy. The safe limit for respirable dust concentration was calculated from each worker, then the median value of the safe concentration was taken as $6.08 \mathrm{mg} / \mathrm{m} 3$.

After risk analysis, the next step was to run risk management if the obtained one was the unsafe level of risk, either current risks or future risks. After conducting a risk analysis, we obtained a safe limit value in accordance with anthropometric conditions and current environmental conditions, which was equal to $6.188 \mathrm{mg} / \mathrm{m} 3$. This safe concentration value was chosen because it was the most logical value and most likely to be fulfilled. To achieve this value, the company must make efforts to control the respirable dust.

Control can be done by using a hierarchy of controls, ie. technical, administrative, and the use of personal protective equipment. Technical control can be carried out, among others, by installing local vents on biscuit printing machines as well as on kilns or on machines that have the potential to remove dust to be sucked and stored in dust collector. Separation of the production process is also important to do to prevent contamination of other parts that should not be dusty by installing room insulation or isolating a place or process unit that has high dust content. Wet process can also be done to minimize the spread of dust in the work environment. Administrative control can be done by rotating workers in the production section whose working period is more than 20 years, especially in the processing of raw materials. Health examination in preventive efforts need to be carried out, especially special health examination for workers in production department by prioritizing routine anatomical and physiological examinations. Personal protective equipment that can be used is a mask for reducing dust, especially those measuring under 5 micrograms. Personal protective equipment is the last alternative choice if technical and administrative controls are no longer possible. Types of masks that can be used to reduce dust entering the lungs include the masks of N-95 or N-100 type.

\section{CONCLUSION}

Respiratory dust levels were measured using the NIOSH 7500 method. The measurement was performed using total dust samplers on the workers and it was found that $53.3 \%$ of the total 
respondents exceeded the Threshold Value for respirable dust (NAB=2 $\mathrm{mg} / \mathrm{m} 3$ ) with a concentration between $0.95-5.8 \mathrm{mg} / \mathrm{m} 3$. The assessment of the level of risk in realtime exposure on each worker showed an unsafe level of risk $(R Q>1)$ due to exposure to respirable dust by $13.3 \%$ of the total respondents. These figures indicate the need for dust control by identifying the limits of safe duration, safe concentration, safe frequency, and safe time through the assessment of risk management strategies. The assessment of risk management strategy results in safe duration, safe concentration, safe frequency and safe time. From these assessment, the most logical and most feasible alternative to reduce the level of risk to be safe is to reduce the concentration of respirable dust in work environment until $\leq 2 \mathrm{mg} / \mathrm{m} 3$.

\section{SUGGESTION}

Periodic and special health examination need to be carried out on production workers in accordance with the types of hazards at work, in this case by examining lung and kidney function. Regular monitoring of the work environment needs to be done to ensure that the working environment conditions are still in accordance with the standard guidelines of the work environment used and also to evaluate the work environment control program.

\section{REFERENCES}

Enhealth. (2002). Environmental health risk assessment: guidelines for assessing human health risks from environmental hazards. Libraries Australia, Departement of Health and Ageing

Gehr, et.al. (2010). Particle-Lung Interaction, Lung Biology in Health and Disease, Second Edition. New York: Informa Health Care USA, Inc

Hisham, MA. (2010). Respiratory Hazards Among Egyptian Ceramics Worker. Journal Industrial Health 2 (6)

Neghab, et al. Work releted respiratory symptoms and ventilatory disorders among employees of a cement industry in shiraz, Iran. Tersedia di www.ncbi.nlm.nih.gov

Peraturan Menteri Negara Lingkungan Hidup Nomor 13 Tahun 2010 Tentang Pengelolaan Lingkungan Hidup dan Upaya Pemantauan Lingkungan Hidup dan Surat Pernyataan Kesanggupan Pengelolaan dan Pemantauan Lingkungan Hidup

Peraturan Menteri Tenaga Kerja dan Transmigrasi Nomor 13 Tahun 2011 tentang Nilai Ambang Batas Faktor Kimia di Lingkungan Kerja

Rahman,dkk. (2008). Analisis Risiko Kesehatan Lingkungan Pertambangan Batu Kapur di Sukabumi, Cirebon, Tegal, Jepara dan Tulungagung. Jurnal Ekologi Kesehatan Vol. 7 No. 1.

Suma'mur. (2009). Higiene Perusahaan dan Kesehatan erja Hiperkes. Jakarta: Sagung Solo Suma'mur. 2009. Higiene Perusahaan dan Kesehatan erja Hiperkes. Jakarta: Sagung Solo

Wallaert. (1990). Subclinical alveolitis in immonologic systwmic disorders. tersedia di europrpmc.org

World Health Organization. (1997). International Agency For Research On Cancer. IARC Monographs on the Evaluation of Carcinogenic Risks to Humans. Wood Dust and Formaldehyde. WHO. 
Risk Quotient (RQ) Analysis in Workers Exposed to Respirable Dust in Ceramic Industry

ORIGINALITY REPORT

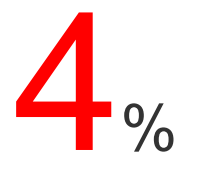

SIMILARITY INDEX
$3 \%$

INTERNET SOURCES
$2 \%$

PUBLICATIONS
$1 \%$

STUDENT PAPERS

PRIMARY SOURCES

1 www.houstoncommunitybank.com

Internet Source

2 WWW.scribd.com

Internet Source

3 www.indianjournals.com

Internet Source

4 e-journal.unair.ac.id Internet Source

5 Submitted to Universitas Airlangga Student Paper

6 Beugeling, W., N. Goldman, and C. Smith. "Topological phases in a two-dimensional lattice: Magnetic field versus spin-orbit coupling", Physical Review B, 2012.

\section{Publication}

$7 \quad$ www.uwa.edu.au 
8 Pramadita. "PENGARUH KEBISINGAN TERHADAP KOMUNIKASI PEKERJA PABRIK PT. X, KECAMATAN MANIS MATA, KABUPATEN KETAPANG", Jurnal Teknologi

Lingkungan Lahan Basah, 2018

Publication

9

William B. Coate, William M. Busey, Warren H. Schoenfisch, Nancy M. Brown, Elvin A.

Newmann. "Respiratory toxicity of enzyme

detergent dust", Toxicology and Applied

Pharmacology, 1978

Publication

Exclude quotes

Off

Exclude matches

Off

Exclude bibliography

On 


\section{Risk Quotient (RQ) Analysis in Workers Exposed to Respirable Dust in Ceramic Industry}

GRADEMARK REPORT

FINAL GRADE

10

PAGE 1

PAGE 2

PAGE 3

PAGE 4

PAGE 5

PAGE 6

PAGE 7

PAGE 8
GENERAL COMMENTS

Instructor 